\title{
USE OF MOBILE PHONE AND INTERNET: ADOLESCENT PERCEPTIONS
}

\section{B. PRASHANTHI \& S. RATNA KUMARI}

Department of Human Development and Family Studies, College of Home Science,

Acharya N.G. Ranga Agricultural University, Hyderabad, India

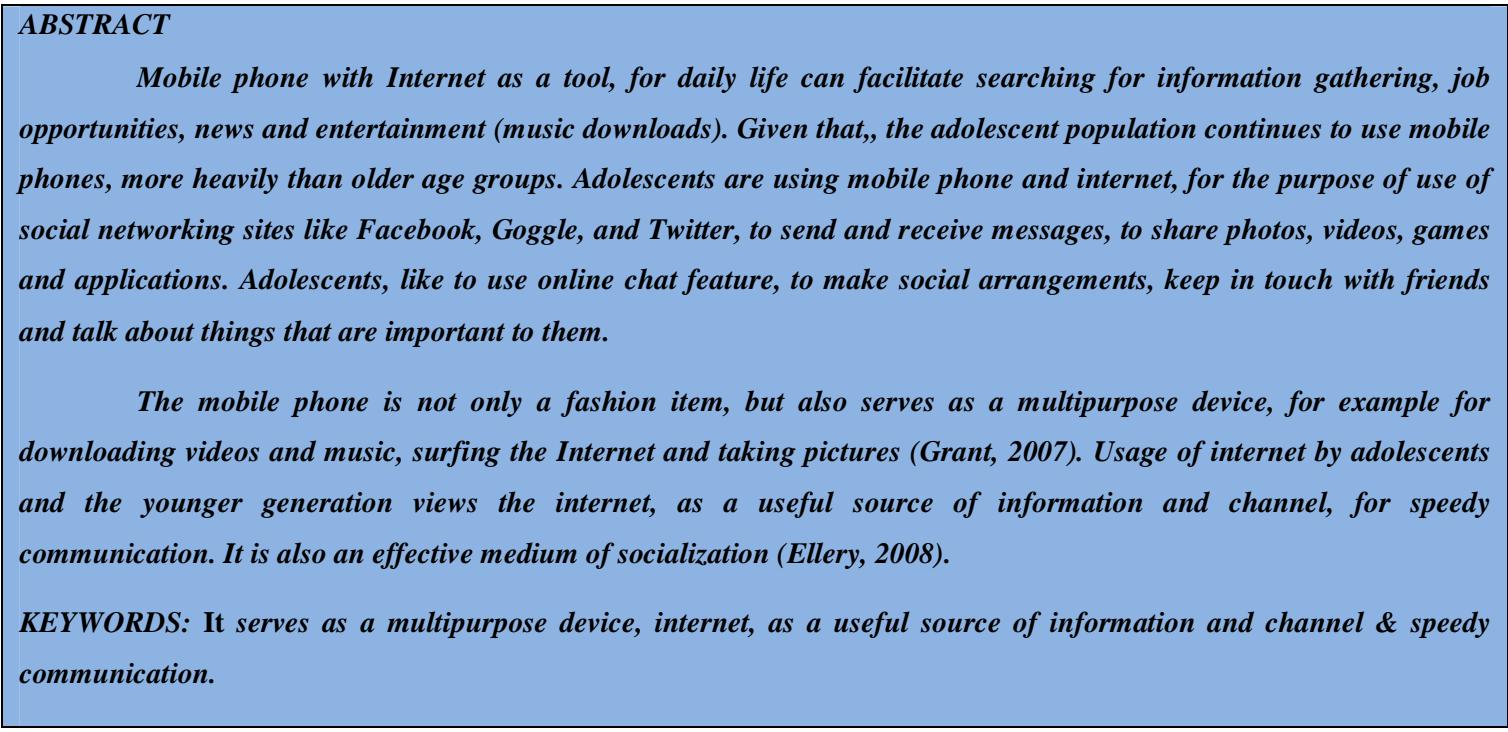

Received: Aug 17, 2017; Accepted: Sep 03, 2017; Published: Sep 08, 2017; Paper Id.: IJCMSOCT20172

\section{INTRODUCTION}

Boneva, et al., (2006) study on adolescents, expressed that, the Internet has become indispensable for instrumental purposes such as, college work and information gathering, as well as for communication purposes. The communication applications of the Internet, such as e-mail, instant messaging, blogs, and chat rooms have entrenched themselves, in the lives of adolescents.

Borzekowski and Rickert (2001), have explored the adolescents' perceptions and experiences of using the internet, to find information about health and medicines. These studies show that, the Internet is the primary general information source for adolescents, regardless of their socioeconomic and ethnic backgrounds, and that, most health information is accessed through search engines with a high success rate. Campbell (2008) found that, adolescent's perception about mobile phone was to give more security and safety.

The present study was conducted to study the adolescent perceptions, on the use of mobile phone and internet. Hyderabad was purposively selected, for conducting the study of the sample, which consisted of 200 adolescents, between the ages of 18- 21 years. The data were collected, by using the questionnaire. The collected data was scored, tabulated, analyzed and interpreted with appropriate statistical procedures. 
Use of Mobile Phone and Internet by Adolescents

Table 1: Perceptions of Sample on Importance of Mobile Phone N=200

\begin{tabular}{|c|c|c|c|c|c|c|c|c|c|c|c|}
\hline \multirow{3}{*}{ S. No } & \multirow{3}{*}{$\begin{array}{l}\text { Mobile Phone is } \\
\text { Important in One's } \\
\text { Life }\end{array}$} & \multicolumn{4}{|c|}{ 18-19 Years } & \multicolumn{4}{|c|}{ 20-21 Years } & \multirow{2}{*}{\multicolumn{2}{|c|}{ Total }} \\
\hline & & \multicolumn{2}{|c|}{ Boys } & \multicolumn{2}{|c|}{ Girls } & \multicolumn{2}{|c|}{ Boys } & \multicolumn{2}{|c|}{ Girls } & & \\
\hline & & No & $\%$ & No & $\%$ & No & $\%$ & No & $\%$ & No & $\%$ \\
\hline 1. & Strongly Agree & 11 & 22 & 11 & 22 & 9 & 18 & 9 & 18 & 40 & 20 \\
\hline 2. & Agree & 26 & 52 & 25 & 50 & 7 & 14 & 26 & 52 & 84 & 42 \\
\hline 3. & Undecided & 8 & 16 & 8 & 16 & 4 & 8 & 5 & 10 & 25 & 12 \\
\hline 4. & Disagree & 3 & 6 & 6 & 12 & 18 & 36 & 6 & 12 & 33 & 16 \\
\hline 5. & Strongly disagree & 2 & 4 & 0 & 0 & 12 & 24 & 4 & 8 & 18 & 9 \\
\hline & Total & 50 & & 50 & & 50 & & 50 & & 200 & \\
\hline
\end{tabular}

From the above table, it can be observed that, fifty percent of boys and girls belonging to a lower age group agreed that, mobile phone is important in one's life. Whereas, nearly 36 percent of boys of 20-21 years, disagreed with the statement that, mobile phone is important in every one's life. Whereas, 52 percent of girls agreed that, mobile phone is important in one's life. Finally, this table indicates that, 42 percent of the students agreed that mobile phone is important in one's life and 20 percent strongly agreed with the statement. The reasons for the above results could be that, cell phone has become a necessary and important tool to communicate with people.

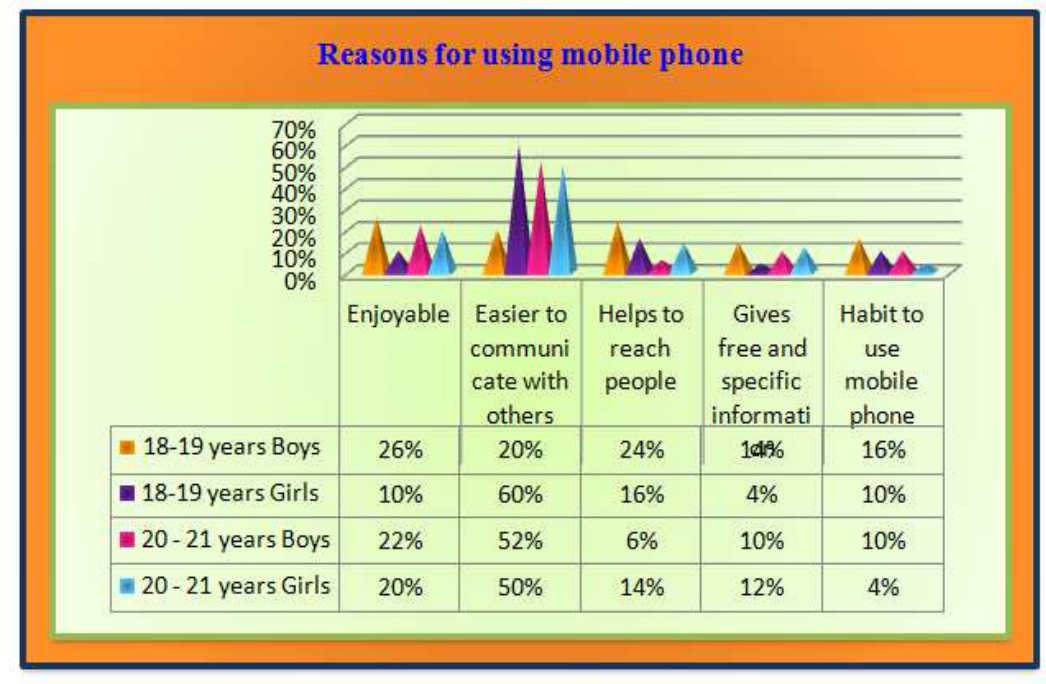

Figure 1: Reasons for Using Mobile Phone

The above graph indicates that, sixty percent of girls in 18-19 years age group stated that, the mobile phone is used to easily communicate with others. But least percent of boys and girls (10\%) mentioned that, it has become a habit. In the age group of 20-21 years, fifty percent of both boys and girls mentioned that, it was used for easy communication and only 20 percent stated that, mobile phone gives enjoyment. Whereas less percent $(10 \%)$ stated that, mobile phone gives free and specific information.

From the study, it was observed that, boys from both the age groups were spending more than 2 hours with mobile phone for talking; whereas, girls were spending much time in texting the messages. The younger boys were using the internet, through mobiles for more than two hours and girls of the same age was using internet on the mobile phones, only for 1 to 2 hours. Both boys and girls were making phone calls to others, when they were alone and when they have a problem. The majority of the respondents (boys and girls) agreed that, more usage of mobile phones would create more 
problems for themselves.

Table 2: Distribution of Sample on Purpose of Using Internet $\mathrm{N}=200$

\begin{tabular}{|c|c|c|c|c|c|c|c|c|c|c|c|}
\hline \multirow{3}{*}{ S.No } & \multirow{3}{*}{$\begin{array}{c}\text { Purpose of Using The } \\
\text { Internet }\end{array}$} & \multicolumn{4}{|c|}{ 18-19 Years } & \multicolumn{4}{|c|}{ 20-21 Years } & \multirow{2}{*}{\multicolumn{2}{|c|}{ Total }} \\
\hline & & \multicolumn{2}{|c|}{ Boys } & \multicolumn{2}{|c|}{ Girls } & \multicolumn{2}{|c|}{ Boys } & \multicolumn{2}{|c|}{ Girls } & & \\
\hline & & No & $\%$ & No & $\%$ & $\overline{\text { No }}$ & $\%$ & No & $\%$ & No & $\%$ \\
\hline 1. & Information gathering & 10 & 20 & 22 & 44 & 15 & 30 & 27 & 54 & 74 & 37 \\
\hline 2. & Games & 18 & 36 & 8 & 16 & 7 & 14 & 8 & 16 & 41 & 20 \\
\hline 3. & Movies & 7 & 14 & 2 & 4 & 8 & 16 & 6 & 12 & 23 & 11 \\
\hline 4. & T.V Shows & 4 & 8 & 1 & 2 & 0 & 0 & 2 & 4 & 7 & 3 \\
\hline 5 & Music Albums & 11 & 22 & 17 & 34 & 16 & 32 & 7 & 14 & 51 & 25 \\
\hline 6. & $\begin{array}{l}\text { Any other (Video is } \\
\text { chatting) }\end{array}$ & 0 & 0 & 0 & 0 & 4 & 8 & 0 & 0 & 4 & 2 \\
\hline & Total & 50 & & 50 & & 50 & & 50 & & 200 & \\
\hline
\end{tabular}

The above table clearly indicates that, in 18-19 years age group, 36 percent of boys mentioned that, they use the internet only for games. Nearly 44 percent girls of the same age group, use the internet for information gathering. In the 20-21 years age group, 32 percent of boys mentioned that, they use the internet for music albums. Fifty four percent of girls mentioned that, they use the internet for information gathering, which is more than the younger age group. Thirty seven percent of total samples, used internet only for information gathering, because half of the girls irrespective of the age were using the internet only for information gathering. Another 25 percent of them used the internet, for downloading music albums. The purpose of using internet by most of the adolescents was, for gathering information which might be because, they are pursuing their studies and also to improve their knowledge and to know the news that happens in the surroundings.

With regard to the usage of internet, adolescents preferred to spend much time in online at home, compared to college and have at least two social networking websites. From both the age groups, boys and girls were spending much time on the internet. Facebook, was very popular among graduate college students, irrespective of the gender and age group.

\section{Adolescent Perceptions on Use of Mobile Phone and Internet}

Results on adolescents' perceptions, on usage of mobile phone and internet indicated that, nearly 59 percent of the students said that, they use mobile phones in college. Nearly 89 percent of the students said that, the mobile phone is useful to keep contact with friends and family. Thirty two percent of boys and girls reported that, they never shut down their mobile phone and the only reason for shutting down the mobile phones was, during examinations.

Reason for changing mobile phone was, because of the new technology they were getting attracted. Some never changed mobile phones, because of their favourite models. Both the age groups perceived that, communication was the best thing and radiation was the worst thing, in using mobile phones. Ninety four percent of the students accepted that, they have Email ID. Eighty two percent of the students said that, the internet is responsible for many of the good things for e.g.. Enjoyment. Both the age groups reported that, information gathering was the best thing and becoming addicted, was the worst thing about the internet.

There was no significant difference, found between age and gender with respect to usage of mobile phone and internet in a day. In the age group of 18-19 years, there was no significant difference between boys and girls. Further, there was a significant difference on usage of mobile phone in a day, between 20-21 years. There was no significant difference 
between age and gender, on the usage of internet.

The reasons for the above results could be explained to the factors that, there was less difference in the age range of the sample because, the entire 200 hundred students fell in the age range of 18-21 years, hence, the entire sample had a similar usage pattern, with respect to mobile phone and internet.

The reasons for no significant difference between the genders could be explained to the factors that, mobile phone and internet are powerful communication devices, which erased the gender differences with regard to usage as well as perceptions, on mobile phone and internet. It can be concluded that, the sample did not show any difference with regard to usage and perceptions.

\section{SUMMARY}

- A maximum number of the adolescents were using mobile phones at a medium range.

- Most of the respondents used social networking website i.e., face book.

- The boys were spending more than 2 hours, with mobile phone for talking, whereas, girls were spending much time in texting the messages.

- The younger boys were using the internet on their mobiles, for more than two hours, whereas, girls of the same age were using the internet, on the mobile phones only for 1 to 2 hours.

- Students preferred to spend much time on online at home, compared to college and have at least 2 social networking websites.

- Lower age group (18-19 years) boys were using the internet only for games where as the girls were using the internet for information gathering.

- A higher age group boys and girls were using the internet for information gathering. Both the age groups spend 1 to 2 hours time, on the internet.

- Both the age groups reported that, information gathering was the best thing and becoming addicted, was the worst thing about the internet.

\section{REFERENCES}

1. Boneva, B. S., Quinn, A., Kraut, R. E., Kiesler, S. And Shklovski, I. 2006. Teenage communication in the Instant Messaging era. In R. Kraut, M. Brynin, and S. Kiesler (Eds.), Information technology at home. New York: Oxford University Press.

2. Borzekowski, D. L. G. And V. I. Rickert. 2001a. "Adolescents, the Internet, and Health: Issues of Access and Content." Journal of Applied Developmental Psychology 22 (1): 49-59.

3. Campbell, R. 2006. Teenage girls and cellular phones: Discourses of independence, safety and 'rebellion.' Journal of Youth Studies, 9 (2), 195-212.

4. Ellery, K. 2008. An investigation into electronic -source plagiarism in a first year essay assignment. Informal World, 33 (6), 607-617.

5. Grant, I. 2007. Why young consumers are not open to mobile marketing communication. International Journal of Advertising, 26 (2), 223-246. 